\title{
Stem cell isolation by a morphology-based selection method in postnatal mouse ovary
}

\author{
Soraya Parvari ${ }^{1}$, Mehdi Abbasi ${ }^{1}$, Niloufar Abbasi², Valliollah Gerayeli Malek³, Fardin Amidi', \\ Fereydoon Sargolzaei Aval ${ }^{4}$, Mehryar Habibi Roudkenar ${ }^{5}$, Fariburz Izadyar ${ }^{6}$
}

\author{
${ }^{1}$ Department of Anatomy, Faculty of Medicine, Tehran University of Medical Sciences, \\ Tehran, Iran \\ ${ }^{2}$ Faculty of Medicine, Tehran Medical Branch, Islamic Azad University, Tehran, Iran \\ ${ }^{3}$ Department of Iranian Traditional Medicine, Tehran University of Medical Sciences, \\ Tehran, Iran \\ ${ }^{4}$ Department of Anatomy, Faculty of Medicine, Zahedan University of Medical \\ Sciences, Zahedan, Iran \\ ${ }^{5}$ Research Center, Iranian Blood Transfusion Organization (IBTO), Tehran, Iran \\ ${ }^{6}$ PrimeGen Biotech, Irvine, USA
}

Submitted: 11 March 2013

Accepted: 29 July 2013

Arch Med Sci 2015; 11, 3: 670-678

DOI: 10.5114 /aoms.2015.52374

Copyright $\odot 2015$ Termedia \& Banach

\section{Abstract}

Introduction: An increasing body of evidence has emerged regarding the existence and function of spermatogonial stem cells (SSCs); however, their female counterparts are the subject of extensive debate. Theoretically, ovarian germ stem cells (GSCs) have to reside in the murine ovary to support and replenish the follicle pool during the reproductive life span. Recently, various methods have been recruited to isolate and describe aspects of ovarian GSCs, but newer and more convenient strategies in isolation are still growing. Herein, a morphology-based method was used to isolate GSCs.

Material and methods: A cell suspension of mouse neonatal ovaries was cultured. Colonies of GSCs were harvested mechanically and cultivated on mouse embryonic fibroblasts (MEF). Alkaline phosphatase activity was assessed to verify stemness features of cells in colonies. Expression of germ and stem cell specific genes (Oct-4, Nanog, Fragilis, C-kit, Dazl, and Mvh) was analyzed by reverse transcription-polymerase chain reaction (RT-PCR). Immunofluorescence of Oct4, Dazl, Mvh, and SSEA-1 was also performed.

Results: Small colonies without a clear border appeared during the first 4 days of culture, and the size of colonies increased rapidly. Cells in colonies were positive for alkaline phosphatase activity. Reverse transcription-polymerase chain reaction showed that Oct-4, Fragilis, C-kit, Nanog, Mvh, and Dazl were expressed in colony-forming cells. Immunofluorescence revealed a positive signal for Oct4, Dazl, Mvh, and SSEA-1 in colonies as well.

Conclusions: The applicability of morphological selection for isolation of GSCs was verified. This method is easier and more economical than other techniques. The availability of ovarian stem cells can motivate further studies in development of oocyte and cell-based therapies.

Key words: stem cells, ovary, isolation, mice.

\section{Introduction}

The increasing number of infertile patients has provoked many studies to investigate the feasibility of gamete generation in vitro. The ef-

\author{
Corresponding author: \\ Mehdi Abbasi \\ Department \\ of Anatomical Sciences \\ School of Medicine \\ Tehran University \\ of Medical Sciences \\ Poursina St., Keshavarse Ave \\ Tehran, Iran \\ Phone: + 9802166419072 \\ Fax: +9802166419072 \\ E-mail: abbasima@tums.ac.ir
}


ficient differentiation of stem cells into different cell lineages has provided promising potential therapies for several diseases [1-4]. Embryonic, adult, and gonadal stem cells have been proposed as likely sources from which germ cells can be obtained [5-9]. Particularly in reproductive science, some successful methods have shown dramatic improvement in treatment of infertility via production of germ cells from stem cells [10]. In male mammals, the existence and differentiation capability of spermatogonial stem cells (SSC) as well as their role in spermatogenesis maintenance and self-renewal after birth have been confirmed in several studies [11-13]. However, their female counterparts are still highly controversial owing to a basic dogma in reproductive biology concerning a fixed number of oocytes in the ovary at birth and no additional formation during postnatal development [14-19]. The idea of a stable population of oocytes has been challenged by several studies supporting postnatal development of oocytes (folliculogenesis) in female mouse ovaries [20-22]. Atresia and ovulation during adult life in mouse decrease the pool of follicles progressively and lead to its depletion, which results in an inadequate reproductive life span. Therefore, a substitute source of follicles is mandatory to replenish and stabilize the pool during the reproductive age. Germ stem cells (GSCS) in the ovary could function in providing new follicles.

A growing body of evidence reinforces the existence and properties of GSCs. Expression of germ cell and stem cell-specific markers, such as mouse vasa homologue (Mvh/VASA), Oct-4, Nanog, Sox-2, stage-specific embryonic antigen-4, and C-kit in surface epithelium (germinal epithelium) of postnatal mouse ovaries has suggested these spheroid cells as a candidate of GSCs [22-26]. In the same line, synaptonemal complex protein 3 (SCP3), a meiosis and germ cell-specific protein, has been detected in the ovarian samples in significantly higher levels than in the testis and extragonadal tissue [27]. Furthermore, positive immunolabeling of germ cell nuclear antigen (GCNA) and proliferating cell nuclear antigen (PCNA) has further confirmed the postnatal renewal of follicles in adult mouse ovaries [28].

Fluorescence-activated cell sorting (FACS) [29] and magnetic-activated cell sorting (MACS) [22, 30] have been utilized by several groups to isolate germ cells from postnatal ovaries. Production of offspring is the most valid and gold standard proof for existence of GSCs in the ovary. In a study, Mvh positive cells, which were isolated from neonatal mouse ovaries by MACS, showed normal karyotype and high telomerase activity besides their interesting potential of offspring production [22]. Another study utilized transgenic mice expressing green fluorescent protein (GFP) under the control of Oct-4 promoter to isolate GSCs using FACS. The GFP positive cells were characterized and successfully differentiated toward oocytes [29]. Above-mentioned evidence emphasized the notion of postnatal persistence of GSCs, which contribute to the renewal of the follicle pool (folliculogenesis).

Some scientists have used morphology-based selection in order to enrich SSCS. They isolated testicular cells by an enzymatic procedure. After cultivation of total testicular cells, typical morphology colonies were transferred to a new feeder dish [31]. Also, other researchers collected colony forming cells from ovarian cells that had been seeded onto an murine embryonic fibroblast (MEF) monolayer [32].

In the present study, we found that embryonic stem cell-like cells can be yielded from neonatal mouse ovaries. Since morphology selection is much easier and more profitable than FACS and MACS techniques, morphology-based selection has been used as a new strategy to purify ovarian stem cells and enrich their colonies.

\section{Material and methods}

All procedures were carried out according to the ethics committee of Tehran University of Medical Sciences and all animal experiments were approved by the institutional animal care and use committee, and were performed in accordance with university guidelines.

\section{Feeder cell preparation}

To obtain MEF, 13.5-day post coitus fetuses of CD-1 mouse were sacrificed. Placenta, fetal membranes, visceral organs, head, and extremities of the fetuses were removed under a dissecting microscope. The embryonic tissue was minced and transferred to an Erlenmeyer flask containing $5 \mathrm{ml}$ of trypsin-EDTA (Invitrogen, Grand Island, NY), a stirrer bar, and a few $5 \mathrm{~mm}$ glass beads; then, it was stirred for 15 to 25 min with a magnetic stirrer. The suspension was filtered through a cell strainer and centrifuged at $450 \mathrm{~g}$ for $5 \mathrm{~min}$ at room temperature. The cell pellet was resuspended and counted using a Neubauer slide. $2 \times 10^{6}$ cells were transferred per $100 \mathrm{~mm}$ culture dish in about $3 \mathrm{ml}$ of MEF growth medium (high glucose Dulbecco's Modified Eagle Medium (DMEM) supplemented with $15 \%$ fetal bovine serum (FBS) and $1 \%$ penicillin/streptomycin) and maintained at $5 \% \mathrm{CO}_{2}$ and $37^{\circ} \mathrm{C}$ for $24 \mathrm{~h}$. After $24 \mathrm{~h}$, the medium was refreshed to remove debris, erythrocytes, and unattached cellular aggregates, and was cultivated for an additional 1 to 2 days to yield $90 \%$ confluence. Thereafter, MEF were inactivated in a medium containing mitomycin $\mathrm{C}(10 \mathrm{mg} / \mathrm{ml})$ at 
$37^{\circ} \mathrm{C}$ for $3 \mathrm{~h}$. Finally, MEF were trypsinized and replated on gelatin-coated $(0.1 \%)$ 4-well plates at a density of 50000 to 60000 cells $/ \mathrm{cm}^{2}$ [31].

Isolation of neonatal ovarian stem cell-like cells using cell morphology

To prepare the ovarian cells, 20 to 30 ovaries from 5- to 7-day-old mice were dissected under a dissecting microscope and collected in ice-cold Dulbecco's phosphate-buffered saline (D-PBS). After centrifugation, D-PBS was removed and the ovaries were transferred to Hank's balanced salt solution (HBSS) without calcium and magnesium containing collagenase (1 mg/ml, Type IV; Invitrogen, Grand Island, NY) and DNase (10 U/ml, type I; Sigma, St. Louis, MO) for $45 \mathrm{~min}$ at $37^{\circ} \mathrm{C}$. To speed up disruption of ovaries, the digestion suspension was pipetted at 10-minute intervals. The dissociated cells were centrifuged at $400 \mathrm{~g}$ for $5 \mathrm{~min}$. The cell pellet was resuspended and then passed through a $70 \mu \mathrm{m}$ nylon cell strainer. A pre-plate culture was performed for 30 min to decrease fibroblast contamination. The buoyant cells were transferred onto gelatin-coated $60 \mathrm{~mm}$ culture dishes in DMEM supplemented with $0.1 \mathrm{mM} \beta$-mercaptoethanol (Sigma, St. Louis, MO) 1\% (v/v) nonessential amino acids (Invitrogen, Grand Island, NY), 2 mM L-glutamine (Sigma, St. Louis, MO), 1\% $(\mathrm{v} / \mathrm{v})$ lyophilized mixture of penicillin and streptomycin (Invitrogen, Grand Island, NY), 5000 units/ $\mathrm{mL}$ mouse leukemia inhibitory factor (LIF; Sigma, St. Louis, MO), and $15 \%(\mathrm{v} / \mathrm{v}) \mathrm{FBS}$ at $37^{\circ} \mathrm{C}$ under $5 \% \mathrm{CO}_{2}$ in a humidified air atmosphere. After cultivation of total ovarian cells on gelatin-coated dishes for 7 to 10 days, ovarian stem cells formed small colonies and showed their typical morphology.

These colonies were mechanically removed using a capillary pipette, and transferred onto the inactivated MEF monolayer. The colonies were passaged at intervals of 3 days and the medium was changed daily. The LIF concentration in the culture medium was reduced to 1000 units $/ \mathrm{ml}$ after the primary culture.

\section{Alkaline phosphatase activity}

The alkaline dye was prepared by dissolving a fast red naphthol-Tris buffer tablet in $10 \mathrm{ml}$ of deionized water (Sigma, St. Louis, MO). Cells were fixed in $10 \%$ formaldehyde for 10 min followed by two sequential washes with $0.2 \mathrm{M}$ Tris. Alkaline dye was added to cells and they were incubated for $30 \mathrm{~min}$ at $37^{\circ} \mathrm{C}$. Cells were washed and visualized using an inverted microscope.

\section{Immunofluorescence}

For fluorescent immunocytochemistry, cells were fixed in 4\% paraformaldehyde (Merck, Darm- stadt, Germany) for 15 min and rinsed twice with cold PBS ( $\mathrm{pH} 7.4$ ), followed by permeabilization with $0.2 \%$ TritonX-100 (Sigma, St. Louis, MO) for 15 min. Non-specific binding sites were blocked with $1 \%$ bovine serum albumin (Sigma, St. Louis, MO) at $37^{\circ} \mathrm{C}$ for $30 \mathrm{~min}$. Primary antibodies against Oct-4 (rabbit polyclonal to Oct4; Abcam), SSEA1 (MS MAb to SSEA1 MC480; Abcam), and germ cell markers, such as DAZL (rabbit polyclonal to DAZL; Abcam) were diluted in blocking buffer and incubated overnight at $4^{\circ} \mathrm{C}$. Following three washes, FITC-conjugated secondary antibody (goat polyclonal secondary to rabbit IgG; Abcam) (Rb PAb to ms IgG + IgM + IgA FITC; Abcam) was added for $1 \mathrm{~h}$ at room temperature in the dark. Nuclear counter staining was carried out with 4',6-diamidino-2-phenylindole (DAPI; Sigma, St. Louis, MO) for $1 \mathrm{~min}$. For negative controls, the primary antibody was omitted. Cells were analyzed under a fluorescent microscope (Nikon, Germany).

\section{RNA extraction, cDNA synthesis, and $R T-P C R$ reaction}

Total cellular RNA was extracted using Trizol reagent (Invitrogen, Grand Island, NY) according to the manufacturer's instructions, and examined for purity and concentration using a photometer (NanoDrop ND). Possible DNA contamination was removed by DNase I (Sigma, St. Louis, $\mathrm{MO}$ ) incubation for $30 \mathrm{~min}$ at $37^{\circ} \mathrm{C}$. One $\mu \mathrm{g}$ RNA and primers (Bioneer, CycleScript RT PreMix) were utilized for cDNA synthesis (complementary cDNA synthesis kit, Bioneer, South Korea). Polymerase chain reaction was performed using GeneAmp PCR system 9600 (PerkinElmer Life and Analytical Sciences, Wellesley, MA). Specific primer pairs of Oct-4, Nanog, C-kit, Fragilis, Dazl, Mvh, SCP3, and GDF9 (growth differentiation factor 9) (Table I) were used for PCR reaction. Cycling parameters were as follows: $5 \mathrm{~min}$ initial denaturation at $94^{\circ} \mathrm{C}$, then 33 cycles at $94^{\circ} \mathrm{C}$ for $30 \mathrm{~s}$, corresponding to the annealing temperature of primer pairs for $30 \mathrm{~s}$, and $72^{\circ} \mathrm{C}$ for $1 \mathrm{~min}$.

Ovarian cells from adult ovaries were used as positive controls and liver cells as negative controls. Polymerase chain reaction products were loaded on $2 \%$ agarose gel, stained with ethidium bromide, and visualized by UVItec Cambridge-Gel Documentation Systems (CB4 1QB-UK). Expression of $\beta$-actin as a housekeeping gene was evaluated as an internal control.

\section{Results}

Isolation of neonatal ovarian stem cell-like cells by morphology selection

Since the main objective of this study was to establish and isolate stem cell-like cells of neona- 
Table I. Sequence, amplicon size and annealing temperature of primer pairs

\begin{tabular}{|lccc|}
\hline Primer pair & \multicolumn{1}{c}{ Sequence } & Product length & Tm \\
\hline Oct-4 & $\begin{array}{l}\text { F: AGTGGGGCGGTTTGAGTAAT } \\
\text { R: GTGTACCCCAAGGTGATCCTC }\end{array}$ & 130 & 59 \\
\hline Fanog & $\begin{array}{l}\text { F: } \text { RGCTCCGCTCCATAACTTCG } \\
\text { R: CATGGCTTTCCCTAGTGGCT }\end{array}$ & 113 & 59 \\
\hline C-kit & $\begin{array}{l}\text { F: AGCCTATGCCTACTCCGTGA } \\
\text { R: GAGGACCAAGGTGCTGATGT }\end{array}$ & 112 & 59 \\
\hline Dazl & $\begin{array}{l}\text { F: CTCACATAGCAGGGAGCACA } \\
\text { R: ACAACTCACCCACACGCATA }\end{array}$ & 123 & 56 \\
\hline Mvh & $\begin{array}{l}\text { F: ATC AGC AAC CAC AAG TCA AG } \\
\text { R: CAA ATC CAT AGC CCT TCG }\end{array}$ & 188 & 54 \\
\hline GDF9 & $\begin{array}{l}\text { F: GCT CAA ACA GGG TCT GGG AAG } \\
\text { R: GGT TGA TCA GTT CTC GAG }\end{array}$ & 145 & $58-59$ \\
\hline SCP3 & $\begin{array}{l}\text { F: GCAGAGAGCTTCCTGTGACC } \\
\text { R: GCCTTTACACCTACGGACA }\end{array}$ & 114 & 55 \\
\hline
\end{tabular}

tal ovary, ovarian cells were cultured from newborn mouse ovaries ( 5 to 8 days) according to the protocol for male GSCs with slight modifications. First, fibroblasts and somatic cells were omitted by the pre-plating technique, which is based on the differential adherent behavior of primary culture cells to a gelatin-coated surface. Floating cells were collected for the secondary culture. During the first 4 days, cells formed small colonies without a clear border (Figures $1 \mathrm{~A}-\mathrm{C}$ ). Colony formation was accelerated when cells were passaged during the first 3 to 4 days. The size of the colonies increased rapidly during 8 to 10 days (Figures 1 D, F). The colonies were dispersed to single cells by trypsinization with difficulty; therefore, we could not count the exact cell number in the colonies.

\section{Characterization of colony forming cells}

Cells in colonies showed a prominent positive signal for Oct4, SSEA1, Mvh and Dazl using immunofluorescence, but owing to the very compact nature of colonies the nuclei of cells were not evident in the center of colonies (Figure 2). Colonies were also positive for alkaline phosphatase as an embryonic stem cell marker (Figure 1 F).

\section{RT-PCR and gene expression analysis}

Colony-forming cells from adult ovarian stem cell-like cells were investigated for the expression of Oct-4 (germ cell-specific transcriptional factor), Fragilis (germ line-specific protein), C-kit (stem cell factor receptor), Nanog (pluripotency sustaining factor), Mvh (germ cell marker), Dazl (germ cell-specific RNA-binding protein), Scp3, and Gdf9 (Figure 3). Reverse transcription-polymerase chain reaction revealed that the cells expressed mRNA for both pluripotent and germ cell markers while they did not express differentiated markers Scp3 and Gdf9 (data not shown).

\section{Discussion}

An alternative source of GSCs would be mandatory for mice reproductive life span if the number of follicles is decreased throughout adult life [23]. A wide variety of reports has suggested the presence of stem cells in the mouse ovaries. Germ cells and mitotically active germ cells have been reported in the postnatal ovary $[5,23,28]$. Restoration of folliculogenesis after the use of anticancer drugs or radiotherapy, which deplete the pool of follicles, is noticeable [20, 33, 34]. Expression of GFP under the control of Oct-4 promoter was an efficient factor for isolation of GSCS of the ovary as the isolated cells differentiated toward oocytes [29]. Production of offspring from Mvh-positive cells of mouse neonatal ovaries is the strongest evidence for the enigmatic existence and identity of GSCs [22].

Various approaches have been recruited to eliminate fibroblasts from cell culture, of which, complement-mediated cytotoxicity using an anti-fibroblast antibody [35, 36] and pre-plating have been frequently used $[32,37]$. Herein, we used pre-plating on a gelatin-coated surface to decrease fibroblasts.

Morphology-based selection, as a strategy, has been applied with the aim of enriching pluripotent cells. Some researchers isolated testicular cells by an enzymatic procedure. After cultivation of total testicular cells, typical morphology colonies were transferred to a new feeder dish [31]. Also, other researchers collected colony forming cells from ovarian cells that had been seeded onto an MEF 

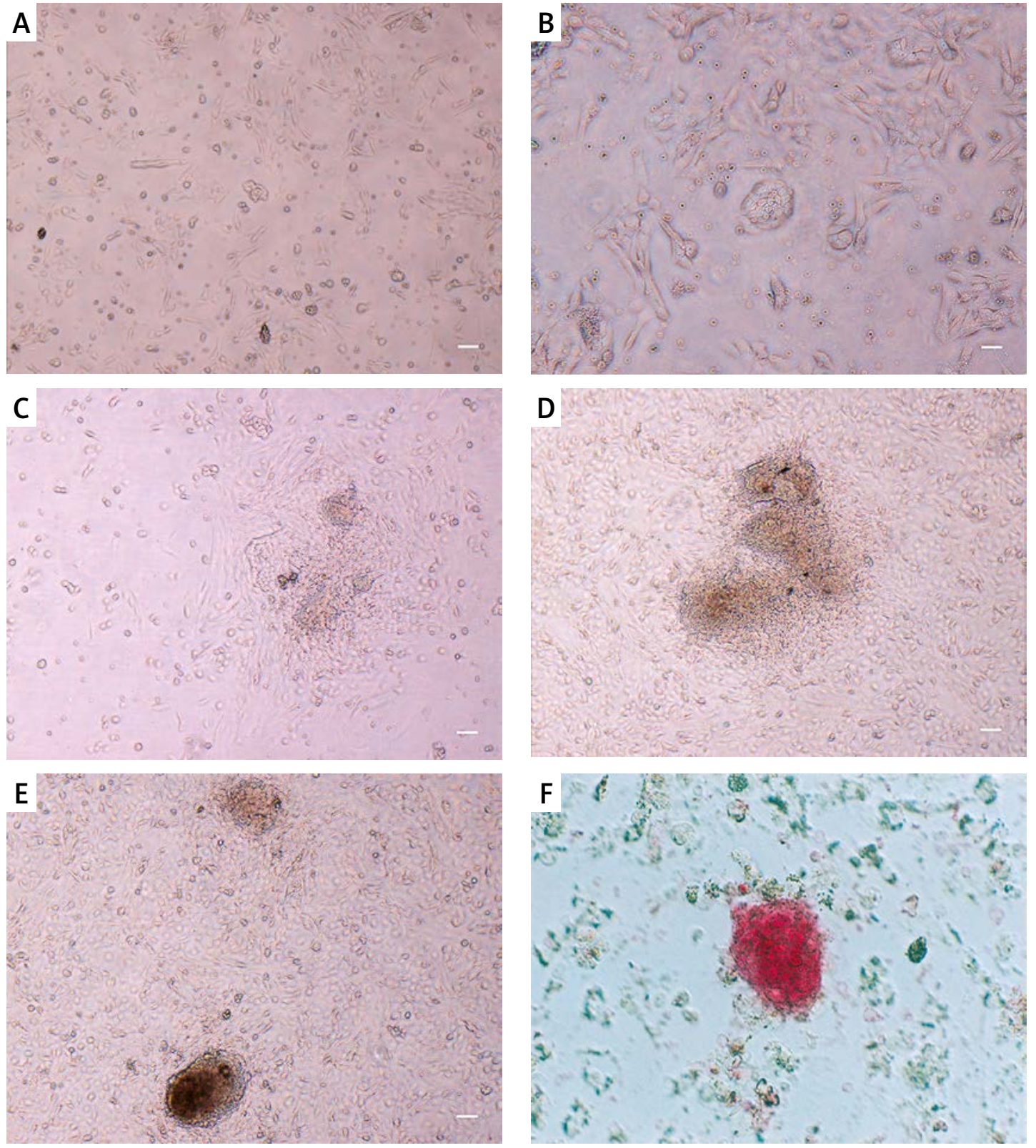

Figure 1. Morphological features of colony forming ovarian stem cells. A - Small colony of ovarian stems during first days of cultivation. B, C - After 2-3 days of cell culture, small SSC colonies were formed. D, E - Colonies enlarged after passage corresponded to days 8 to 10 after isolation. $\mathbf{F}$ - Alkaline phosphatase activity of cells in colonies. Isolated colonies evidently presented the alkaline phosphatase activity which is a well-accepted feature of stem cells with embryonic characterization

Scale bar $=100 \mu \mathrm{m}$.

monolayer [32]. Fully reprogrammed cells could also be isolated by means of colony morphology-based selection [38, 39].

In the present study, we isolated and cultured GSCs based on their colony-forming ability. Isolated cells formed embryonic body-like structures. We isolated a population of small, round cells from mouse ovaries. The small size of these cells and their embryonic characters were similar to very small embryonic-like cells (VSEL). Morphology-based selection was used to enrich SSCs, which is much easier than the FACS technique.
Spermatogonial stem cells can be easily overgrown by other cell types at early stages of derivations. Therefore, mechanical isolation and passage of spermatogonial colonies to a fresh feeder culture plate are vital as soon as they appear [31]. Round spherical colonies could be isolated as thecal stem cells of neonatal ovaries with steroidogenic potential [37]. Colony-forming cells could also be established by co-culturing the ovarian cells with a fibroblast monolayer [32].

Our study showed that ovarian stem cell-like colonies expressed pluripotent and germ cell 

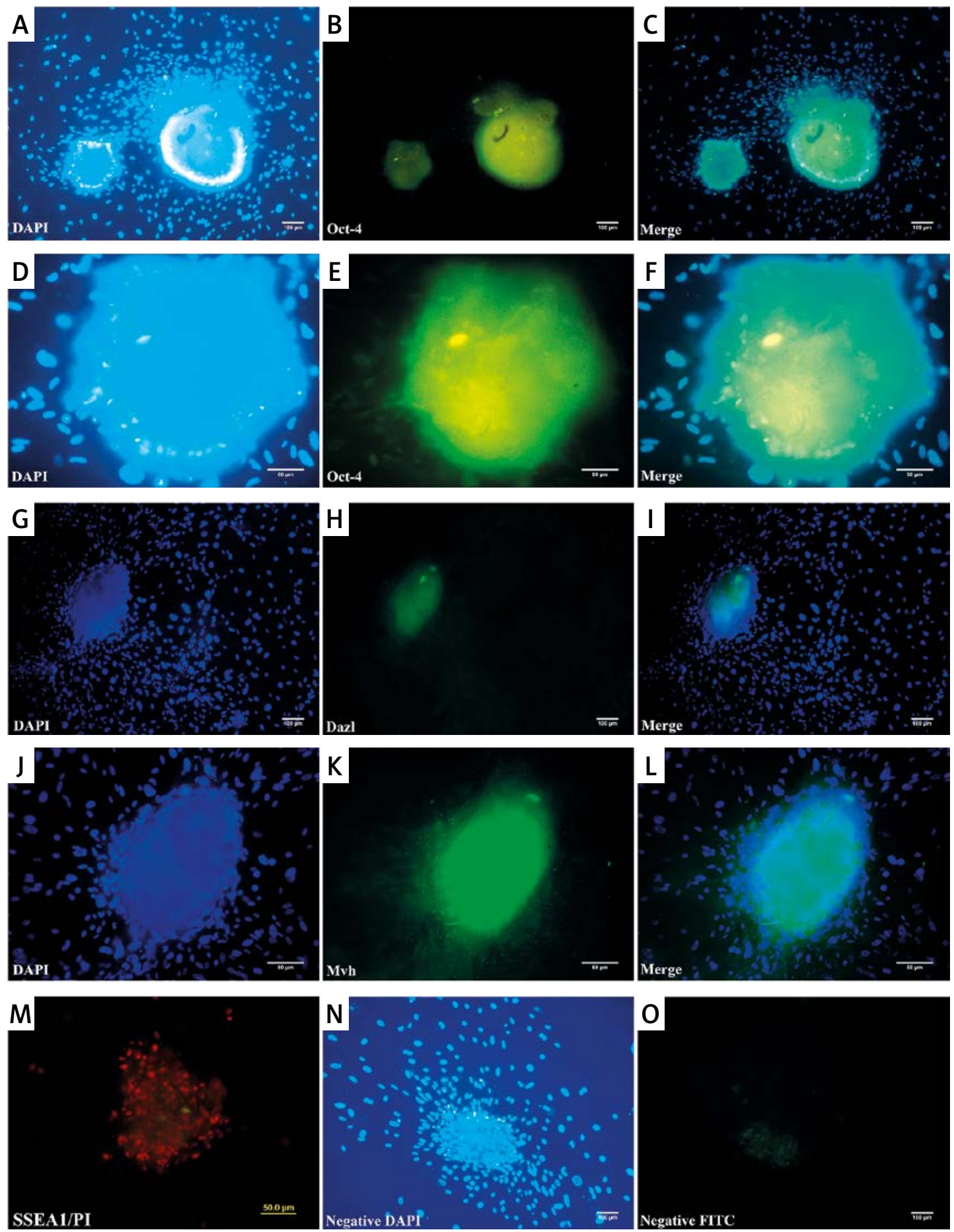

Figure 2. Immunofluorescence of colonies against stem and germ cell specific markers. Oct-4 (A-F), Dazl (G-I),

Mvh (J-L) and SSEA1 (M) were detected in colonies. Cells were counterstained with DAPI and PI (M). High density of cells in colonies prevented the visualization of cells in the center of the colony. $\mathbf{N}$ - Shows higher magnification for OCT4 staining. $\mathrm{N}-\mathrm{O}$ - show the negative control for the detection of OCT4 staining omitting the first antibody

markers, such as Oct-4, Fragilis, Nanog, C-kit, Mvh, and Dazl. Reverse transcription-polymerase chain reaction also confirmed expression of the genes at the mRNA level. The expression of C-kit on these cells probably indicates their primordial germ cell ancestry. Previous studies have reported that many germ/pluripotent markers, such as Oct-4, Mvh, Fragilis, Dazl, and Nanog, are ex- pressed in both pluripotent stem cells and germ cells [40-43]. Although in some previously published experiments female stem cells did not express both GSCs and pluripotent markers [22], our data conform to the study by Pacchiarotti et al. in 2010. They concluded that these cells are probably some oogonia residing in the mouse postnatal ovary [29]. In another study, Dyce et al. reported 


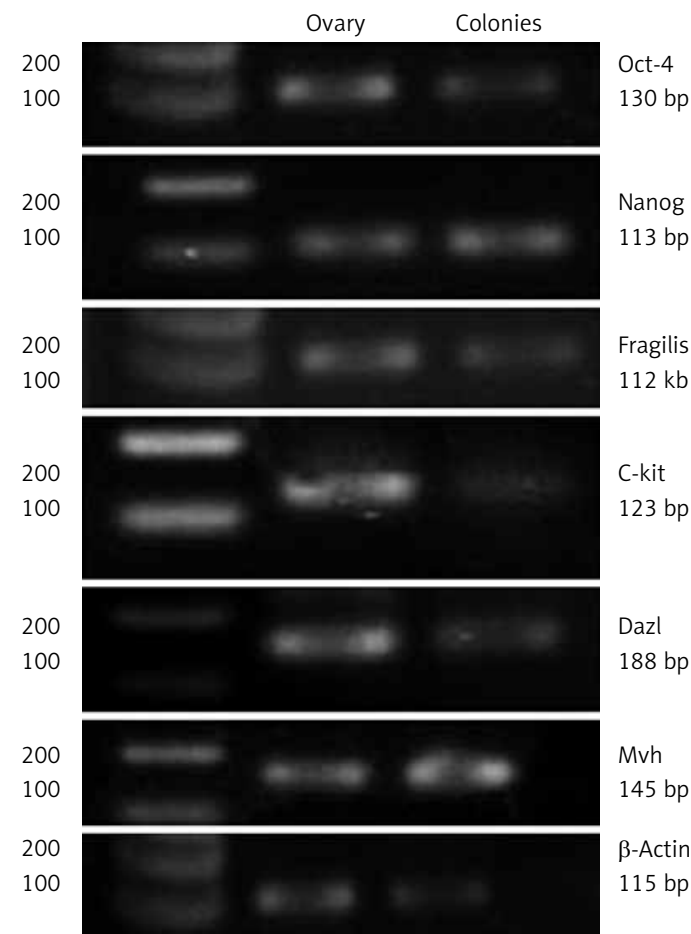

Figure 3. The RT-PCR analysis of stem and germ cell specific markers in colony forming cells. Bands related to the expression of Oct-4, Fragilis, C-kit, Nanog, Mvh and Dazl were observed on gel in the right predicted size. Cells did not express Scp3 and Gdf9 (data not shown). $\beta$-Actin as a housekeeping gene was also studied. Expression profile of ovarian cells from adult ovaries and liver cells were utilized as positive and negative controls, respectively

that stem cells which are derived from newborn mouse skin are capable of differentiating into early oocyte-like cells. They found stem cells that expressed both pluripotent stem cells and germ cells [6]. Colonies in our culture were positive for alkaline phosphatase staining, which is characteristic of embryonic stem cells and embryonic germ cells [13].

Historically, pluripotency-related markers, such as Oct-4 [44] and SSEA-1 [45], have been identified in mice pluripotent embryonic stem cells [46-48]. Oct-4 was originally identified as an ES cell and germ line-specific marker $[49,50]$. At gastrulation, Oct-4 expression is down-regulated and thereafter is maintained only in primordial germ cells [51]. Primordial germ cells, of both males and females, continue to express Oct-4 as they proliferate and migrate to the genital ridges. In the males, the expression of Oct- 4 in germ cells persists throughout fetal development and is maintained postnatally in proliferating gonocytes, prospermatogonia, and undifferentiated spermatogonia. In female germ cells, however, Oct-4 is expressed in gonocytes and undifferentiated oogonia, and undergoes down-regulation during oogenesis, coincident with entry into meiosis, and is up-regulated in the final stage of meiotic prophase I [52].
Stem cells with embryonic character were found in different human and animal adult tissues and organs, including bone marrow, bronchial epithelium, epidermis, myocardium, pancreas, and testes, as reported by Ratajczak et al. They hypothesized that there is a population of embryonic stem cells which persists in adult tissues and organs from the embryonic period of life. These findings agree with a study which reported the presence of stem cells with an embryonic character in some adult tissues and organs [24].

In conclusion, this study verified the presence of ovarian stem cell-like cells in neonatal mouse ovaries that can be isolated and propagated by morphology selection. This provides an unlimited resource and an in-vitro model to study the development of mammalian oocytes, which could be utilized further for the autologous treatment of ovarian infertility and as a promising option for the development of stem cell therapy models for degenerative diseases as well.

\section{Acknowledgments}

This article is part of the thesis for a PhD degree that was supported by Grant 89-01-3010462 from Tehran University of Medical Sciences. The authors are grateful to Dr. M. Naji and Dr. R. Shirazi for their helpful suggestions and technical assistance, to R. Halabian and M. Mohammadpour for their help in RT-PCR, and to $F$. Samani and N. Atlasi for their assistance.

\section{Conflict of interest}

The authors declare no conflict of interest.

\section{References}

1. Nagaya N, Kangawa K, Itoh T, et al. Transplantation of mesenchymal stem cells improves cardiac function in a rat model of dilated cardiomyopathy. Circulation 2005; 112: 1128-35.

2. Yu B, Ma H, Kong L, Shi Y, Liu Y. Enhanced connexin 43 expression following neural stem cell transplantation in a rat model of traumatic brain injury. Arch Med Sci 2013; 9: 132-8.

3. Safwani WK, Makpol S, Sathapan S, Chua K. Impact of adipogenic differentiation on stemness and osteogenic gene expression in extensive culture of human adipose-derived stem cells. Arch Med Sci 2014; 10: 597-606.

4. Soria B, Roche E, Berná G, León-Quinto T, Reig JA, Martín F. Insulin-secreting cells derived from embryonic stem cells normalize glycemia in streptozotocin-induced diabetic mice. Diabetes 2000; 49: 157-62.

5. White YA, Woods DC, Takai Y, Ishihara O, Seki H, Tilly JL. Oocyte formation by mitotically active germ cells purified from ovaries of reproductive-age women. Nat Med 2012; 18: 413-21.

6. Dyce PW, Liu J, Tayade C, Kidder GM, Betts DH, Li J. In vitro and in vivo germ line potential of stem cells derived from newborn mouse skin. PLoS One 2011; 6: e20339. 
7. Zhou GB, Meng QG, Li N. In vitro derivation of germ cells from embryonic stem cells in mammals. Mol Reprod Develop 2010; 77: 586-94.

8. Hübner K, Fuhrmann G, Christenson LK, et al. Derivation of oocytes from mouse embryonic stem cells. Science 2003; 300: 1251-6.

9. Toyooka Y, Tsunekawa N, Akasu R, Noce T. Embryonic stem cells can form germ cells in vitro. Proc Natl Acad Sci USA 2003; 100: 11457-62.

10. Pelosi E, Forabosco A, Schlessinger D. Germ cell formation from embryonic stem cells and the use of somatic cell nuclei in oocytes. Ann N Y Acad Sci 2011; 1221: 18-26.

11. Izadyar F, Pau F, Marh J, et al. Generation of multipotent cell lines from a distinct population of male germ line stem cells. Reproduction 2008; 135: 771-84.

12. Guan K, Nayernia K, Maier LS, et al. Pluripotency of spermatogonial stem cells from adult mouse testis. Nature 2006; 440: 1199-203.

13. Kanatsu-Shinohara M, Inoue K, Lee J, et al. Generation of pluripotent stem cells from neonatal mouse testis. Cell 2004; 119: 1001-12.

14. Bristol-Gould SK, Kreeger PK, Selkirk CG, et al. Fate of the initial follicle pool: empirical and mathematical evidence supporting its sufficiency for adult fertility. Dev Biol 2006; 298: 149-54.

15. Eggan, K, Kreeger PK, Selkirk CG, et al. Ovulated oocytes in adult mice derive from non-circulating germ cells. $\mathrm{Na}$ ture 2006; 441: 1109-14.

16. Telfer EE, Gosden RG, Byskov AG, et al. On regenerating the ovary and generating controversy. Cell 2005; 122 821-2.

17. Silber S, Pineda J, Lenahan K, DeRosa M, Melnick J. Fresh and cryopreserved ovary transplantation and resting follicle recruitment. Reprod Biomed Online 2015; 30: 643-50.

18. Gosden RG. Germline stem cells in the postnatal ovary: is the ovary more like a testis? Hum Reprod Update 2004; 10: 193-5.

19. Hutt KJ, Albertini DF. Clinical applications and limitations of current ovarian stem cell research: a review. J Exp Clin Assist Reprod 2006; 3: 6

20. Johnson J, Bagley J, Skaznik-Wikiel M, et al. Oocyte generation in adult mammalian ovaries by putative germ cells in bone marrow and peripheral blood. Cell 2005; 122: 303-15.

21. Kerr CL, Hill CM, Blumenthal PD, Gearhart JD. Expression of pluripotent stem cell markers in the human fetal ova ry. Hum Reprod 2008; 23: 589-99.

22. Zou K, Yuan Z, Yang Z, et al. Production of offspring from a germline stem cell line derived from neonatal ovaries. Nature Cell Biol 2009; 11: 631-6.

23. Johnson J, Canning J, Kaneko T, Pru JK, Tilly JL. Germline stem cells and follicular renewal in the postnatal mammalian ovary. Nature 2004; 428: 145-50.

24. Virant-Klun I, Zech N, Rozman P, et al. Putative stem cells with an embryonic character isolated from the ovarian surface epithelium of women with no naturally present follicles and oocytes. Differentiation 2008; 76: 843-56.

25. Bukovsky A, Svetlikova M, Caudle MR. Oogenesis in cultures derived from adult human ovaries. Reprod Biol Endocrinol 2005; 3: 17

26. Virant-Klun I, Rozman P, Cvjeticanin B, et al. Parthenogenetic embryo-like structures in the human ovarian surface epithelium cell culture in postmenopausal women with no naturally present follicles and oocytes. Stem Cells Dev 2009; 18: 137-50.
27. Bukovsky A, Caudle MR, Gupta SK, et al. Mammalian neo-oogenesis and expression of meiosis-specific protein SCP3 in adult human and monkey ovaries. Cell Cycle 2008; 7: 683-6.

28. Kerr J, Duckett R, Myers M, Britt KL, Mladenovska T, Findlay JK. Quantification of healthy follicles in the neonatal and adult mouse ovary: evidence for maintenance of primordial follicle supply. Reproduction 2006; 132 : 95-109.

29. Pacchiarotti J, Maki C, Ramos T, et al. Differentiation potential of germ line stem cells derived from the postnatal mouse ovary. Differentiation 2010; 79: 159-70.

30. Zou K, Hou L, Sun K, Xie W, Wu J. Improved efficiency of female germline stem cell purification using fragilis-based magnetic bead sorting. Stem Cells Dev 2011; 20: 2197-204

31. Guan K, Wolf F, Becker A, Engel W, Nayernia K, Hasenfuss $\mathrm{G}$. Isolation and cultivation of stem cells from adult mouse testes. Nat Protoc 2009; 4: 143-54.

32. Gong SP, Lee ST, Lee EJ, et al. Embryonic stem cell-like cells established by culture of adult ovarian cells in mice. Fertil Steril 2010; 93: 2594-601.

33. Krarup T. Effect of 9, 10-dimethyl-1, 2-benzanthracene on the mouse ovary. Ovarian tumorigenesis. Br J Cancer 1970; 24: 168-86.

34. Meirow D, Nugent D. The effects of radiotherapy and chemotherapy on female reproduction. Hum Reprod Update 2001; 7: 535-43.

35. Abboud CN, Duerst RE, Frantz CN, Ryan DH, Liesveld JL, Brennan JK. Lysis of human fibroblast colony-forming cells and endothelial cells by monoclonal antibody (619) and complement. Blood 1986; 68: 1196-200.

36. Singer KH, Scearce RM, Tuck DT, Whichard LP, Denning SM, Haynes BF. Removal of fibroblasts from human epithelial cell cultures with use of a complement fixing monoclonal antibody reactive with human fibroblasts and monocytes/macrophages. J Investig Dermatol 1989; 92: 166-70.

37. Honda A, Hirose $M$, Hara $K$, et al. Isolation, characterization, and in vitro and in vivo differentiation of putative thecal stem cells. Proc Natl Acad Sci 2007; 104: 12389-94.

38. Sommer CA, Mostoslavsky G. Experimental approaches for the generation of induced pluripotent stem cells. Stem Cell Res Ther 2010; 1: 26

39. Meissner A, Wernig M, Jaenisch R. Direct reprogramming of genetically unmodified fibroblasts into pluripotent stem cells. Nat Biotechnol 2007; 25: 1177-81.

40. Mise N, Fuchikami T, Sugimoto $M$, et al. Differences and similarities in the developmental status of embryo-derived stem cells and primordial germ cells revealed by global expression profiling. Genes Cells 2008; 13: 863-77.

41. Yabuta Y, Kurimoto K, Ohinata Y, Seki Y, Saitou M. Gene expression dynamics during germline specification in mice identified by quantitative single-cell gene expression profiling. Biol Reprod 2006; 75: 705-16.

42. Zwaka TP, Thomson JA. A germ cell origin of embryonic stem cells? Development 2005; 132: 227-33.

43. Tsai MS, Hwang SM, Tsai YL, Cheng FC, Lee JL, Chang YJ. Clonal amniotic fluid-derived stem cells express characteristics of both mesenchymal and neural stem cells. Biol Reprod 2006; 74: 545-51

44. Pesce M, Schöler HR. Oct 4: gatekeeper in the beginnings of mammalian development. Stem Cells 2001; 19: 271-8.

45. Ko K, Tapia N, Wu G, et al. Induction of pluripotency in adult unipotent germline stem cells. Cell Stem Cell 2009; 5: 87-96. 
46. Conrad S, Renninger M, Hennenlotter J, et al. Generation of pluripotent stem cells from adult human testis. Nature 2008; 456: 344-9.

47. Kanatsu-Shinohara M, Muneto T, Lee J, et al. Long-term culture of male germline stem cells from hamster testes. Biol Reprod 2008; 78: 611-7.

48. Hua J, Zhu H, Pan S, et al. Pluripotent male germline stem cells from goat fetal testis and their survival in mouse testis. Cell Reprogram 2011; 13: 133-44.

49. Schöler H, Dressler GR, Balling R, Rohdewohld H, Gruss P. Oct-4: a germline-specific transcription factor mapping to the mouse t-complex. EMBO J 1990; 9: 2185.

50. Okamoto K, Okazawa H, Okuda A, Sakai M, Muramatsu $M$, Hamada H. A novel octamer binding transcription factor is differentially expressed in mouse embryonic cells. Cell 1990; 60: 461-72.

51. Yeom YI, Fuhrmann G, Ovitt CE, et al. Germline regulatory element of Oct-4 specific for the totipotent cycle of embryonal cells. Development 1996; 122: 881-94.

52. Pesce M, Gross MK, Schoeler HR. In line with our ancestors: Oct 4 and the mammalian germ. Bioessays 1998; 20: 722-32. 